\title{
Analysis of Ideological and Political Theory Course Practice Teaching in Higher Vocational Colleges
}

\author{
Zhang Shibi \\ Guangxi Vocational \& Technical Institute of Industry, Nanning, Guangxi, 530001
}

\begin{abstract}
Offering vocational college ideological and political education as an important part of the whole teaching activities in higher vocational colleges, is to cultivate the students to have the important course of world outlook, outlook on life, values, moral values of the correct. The practice of Ideological and political theory course teaching is an important link in the current ideological and political theory course teaching reform. In this paper, the connotation of Ideological and political theory teaching from the macro, micro two aspects of the analysis, the connotation and the construction of practice teaching of Ideological and political course of.
\end{abstract}

KEYWORD: Higher vocational; Ideological and political theory course; Practice teaching; Exploration

In 2004 August, the CPC Central Committee, the State Council issued the "on Further Strengthening and improving ideological and political education" (in the opinion of the No. [2004]16) clearly pointed out: "social practice is an important link of Ideological and political education of college students", 2005, the CPC Central Committee Propaganda Department, the Ministry of Education issued "on Further Strengthening and improving college ideological political theory lesson opinions" points out, "all the courses of Ideological and political theories in universities must strengthen the practice link". In this paper, the connotation of Ideological and political theory teaching from the macro, micro two aspects of the analysis, the connotation and the construction of practice teaching of Ideological and political course of.

\section{AN OVERVIEW OF THE IDEOLOGICAL AND POLITICAL THEORY COURSE TEACHINGPRACTICE}

The so-called practice teaching, is a kind of practical education concepts and teaching activities based on the. Usually in the teaching process, the construction of a with educational, creative, practical to the main activities of the students as the main form, to motivate students' active participation, active thinking, active exploration for the basic features, in order to promote the overall quality of the comprehensive development of students for the purpose of teaching form. Ideological and political theory and practice teaching is a teaching activities to train students' world outlook, outlook on life, moral values, pay attention to practice, emphasizes the learners through participation to the feelings of the objective world, is the truth of the teachers to the students, Professor Marx s basic theory and how to get the base, with Marx Lenin doctrine, Mao Zedong thought, Deng Xiaoping the theory and the important thought of "Three Represents" arm the minds of contemporary college students, help them establish a scientific world outlook, outlook on life and values[1].

\section{THE NARROW SENSE OF THE IDEOLOGICAL AND POLITICAL TEACHING}

Ideological and political course practice teaching in the narrow sense, think that the ideological and political course practice teaching should be theory teaching in classroom is different from the traditional, is the use of social practice organization of teaching activities, only out of social practice classroom truly on the significance of practice teaching. Some domestic scholars also think, the socalled practice of Ideological and political theory course teaching, it should be outside the classroom teaching theory, under the guidance of teachers, according to the teaching of the course content and requirements, means and methods of teaching, the other out of the gate, into the community to visit, 
investigation, on-the-spot investigation, personally take part in the social practice that is the meaning of practice teaching. It is outside the classroom teaching. While the students on the platform of lectures, class discussions, case teaching, interactive teaching, discussion, debate, knowledge contest, watch a movie or video, listen to the expert's report and other teaching methods can not be regarded as the practice teaching, extra-curricular activities are just learning theory.

\section{THE BROAD IDEOLOGICAL AND POLITICAL TEACHING}

The main point of generalized ideological and political course practice teaching is: except all related with practice teaching method of theory teaching outside, it can not only reflect the outside of the classroom teaching of Ideological and political theory course, can also be expressed within the classroom teaching of Ideological and political theory course. Both activities students out of the classroom social practice, such as visiting (memorial hall, the sacred place of the revolution), investigation (rural reform and opening advanced factories), service (voluntary service, voluntary labor, social consulting), research (survey report, write academic papers) etc, also include reading, discussion, debate also, lectures and other activities, including case teaching, project teaching, heuristic teaching, teacher's multimedia teaching form", can be in class, also can be in after class; in school, also can be in the school; it can be said that can do".

\section{THE CURRENT IDEOLOGICAL AND POLITICAL COURSE OF THE INSUFFICIENCY EXISTING IN THE TEACHING PRACTICE}

(1) part of Ideological and political theory course teacher there are still theoretical teaching, practice teaching are supplemented by the concept, the practice teaching as an adjunct and supplement the theory teaching, in the concept of understanding is not in place, not the practice teaching of Ideological and political theory course as indispensable a teaching mode.

(2) simply practice teaching into practice teaching in class and outside class, did not do the two blend. Practical teaching activities based on the practical teaching activities in classroom instead of the outside of the classroom, course of Ideological and political theory teaching in the classroom the teacher that part in the use of case analysis, group discussion, cosplay, knowledge competition and practice, there is no need to go to the classroom again the practice teaching, lack of creativity; another kind of circumstance some teachers think that as long as is, lead the students out of school, is the social practice, is the practice teaching, the lack of comprehensive view.

(3) some teachers confused the difference of Ideological and political course of the teaching practice and social practice of college students, think teaching is the holiday social practice, practice investigation, visit, and such activities should be made by the students of the school responsible for the unified organization, student counselor or teacher led to activities, without a clear definition of what is the practice teaching of Ideological and political class, which has affected the development of practice teaching of the ideological and political lessons[2].

\section{ASSOCIATION OF IDEOLOGICAL AND POLITICAL COURSE PRACTICE TEACHING ANDTHEORY TEACHING}

Practice teaching and theory teaching in the class of Ideological and political theory course is different. One is the different cognitive styles. Classroom teaching to highlight the theoretical knowledge instruction, cognitive mode is objective and indirect experience; and the practical application of the subject ability outstanding knowledge teaching into full play, is directly involved in the cognitive styles and subjectiveexperience. Two temporal forms is dif ferent. Classroom teaching is in the fixed time (hours) and solid state space (in the classroom) teaching activities; practice teaching is generally in the flexible time (outside) and open space (SOCIAL) to carry out the. The three is a different functional role. The accumulated memories classroom teaching focused knowledge quantity; optimizing the practice teaching focuses on the theory and the application of knowledge and subject ability. Four is the evaluation of different. Classroom teaching is mainly to test as the basis, focus on the results of evaluation; practice teaching is to experience as the basis, focusing on the process of evaluation.

Although the two have difference, but still have the intrinsic relation, is the ideological and political theory teaching and an integral part of a necessary link. Classroom teaching is the basic premise of practice teaching, practice teaching and deepening classroom teaching experience. The two complement each other, constitute the ideological and political theory course teaching as a whole. The two from different angles, different ways together to complete the task of the ideological and political theory lesson, let the thought politics theory class teaching mode more rich and colorful, more students to accept.

In the modern concept of occupation education, advocate strengthening practical teaching activities. 
Practice teaching course of the ideological and political theory is relatively weak, should strengthen the research on the content of teaching practice, forms of classroom and extracurricular practice teaching, emphasize extracurricular, also should pay attention to practical teaching activities and form within the classroom, highlight the practical teaching scope wide, both "from the classroom into the community" and, "from the society into the classroom" to inside in content and form, and then from outside to inside, so that the content is more rich, more widely, more fine, renew the idea and practice of understanding and political theory course teaching[3].

\section{THE CONSTRUCTION OF PRACTICE TEACHING ACTIVITIES TO ADAPT TO THE IDEA OF MODERN OCCUPATION EDUCATION OF IDEOLOGICAL AND POLITICAL THEORY COURSE}

Pointed out that in May 2, 2014 the country issued (2014) No. 19 "of the State Council on accelerating the development of modern occupation education decision": "to promote the innovation of talent cultivation model. To strengthen the teaching, learning, the combination of training educational and teaching activities. The implementation of the project teaching, case teaching, working process oriented teaching mode. Increase in the proportion of practice teaching."

Therefore, the ideological and political theory course teacher in formulating the syllabus and teaching plan, should be in accordance with the idea of the modern occupation education strengthen practice teaching hours, combined with the characteristics of higher vocational education, the practice teaching hours and theoretical teaching class ratio reached up to $1: 1$, or even more, in the organization of teaching, through the practice of the concept, fully mobilize the enthusiasm of and the students' learning initiative, and actively organize and guide college students to actively participate in the actual life and social practice, actively participate in, experience, active thinking, the theory of knowledge consciously applied to practice, emphasize creativity and practicality, taking the students as the main body, conscious use of theoretical knowledge to analyze and solve practical problems, improve college students' Ideological and moral quality and comprehensive quality, form the correct ideological and political theory of belief.

The practice teaching of Ideological and political theory, whether in the classroom, or outside of the classroom, regardless of the form of teaching or means, should be closely around the syllabus and teaching plan, content, the diversification of forms of occupation, try to expand the practice of Ideological and political theory course teaching extension, according to the teaching curriculum content and the characteristics of students, Ideological and political theory course teachers in teaching, targeted to take the alternation, task driven, project oriented, classroom and practice site integration of action oriented teaching mode, flexibility in the use of case analysis, group discussion, cosplay, enlightening teaching method of teaching, guide students to think actively, be willing to practice; at the same time, it should be properly make full use of modern educational technology (multimedia, software etc.), virtual reality technology, network teaching resources, so as to improve the quality of teaching effectiveness and efficiency, improve the ideological and Political Theory Course Teaching for and effect[4].

In short, to grasp the connotation of learning of Ideological and political theory teaching, recognize the shortcomings of the current ideological and political course in practice teaching of existence, ideological and political course reform, strengthen practice teaching, curriculum so that, in order to better cultivate a new generation of political thought for the national construction useful quality of outstanding students.

\section{REFERENCES}

[1] Wang Xuejian, Li Yongjie. Discussion on College Ideological and political theory course social practice teaching of Ideological and theoretical education guide mechanism of. 2008, 4.

[2] Zhu Zhenyu. Higher Vocational Colleges of Ideological and political theory course practice teaching present situation and countermeasure. Journal of Tianjin Vocational Institute, 2006, 5:16.

[3] Li Shiwen. Construction of Ideological and political theory in Vocational Colleges positioning class practice teaching and mode of higher education. Forum, 2009, 4:110.

[4] Qian Rong. Study on practical teaching of the ideological and political theory course. The ideological and theoretical education, 2007, 3:70-71. 